\title{
VICES OF CONSENT CONCERNING THE CIVIL LEGAL ACT
}

\section{R.D. VIDICAN, I. DIDEA, D.M. ILIE}

\section{PhD student Roxana-Denisa VIDICAN}

Faculty of Juridical and Administrative Sciences,Agora University of Oradea, Romania; Faculty of Law, Doctoral School, “TituMaiorescu” University, Bucharest, Romania.

*Correspondence: Roxana-DenisaVidican, Agora University of Oradea, 8 PiaţaTineretului St., Oradea, Romania

E-mail: vidican.roxana@yahoo.com

\section{PhD ProffessorIonel DIDEA}

Faculty of Economics and Law, University of Pitești, Romania;

Faculty of Law, Doctoral School, "TituMaiorescu" University, Bucharest, Romania, *Correspondence: IonelDidea, University of Pitești, 1 Târgu din Vale St., Pitești, Romania e-mail: prof.didea@yahoo.com

\section{PhD studentDiana Maria ILIE}

Legal and Human Resources Department, University of Pitești, Romania; Faculty of Law, Doctoral School, “TituMaiorescu” University, Bucharest, Romania. *Correspondence: Diana Maria Ilie, University of Pitești, 1 Târgu din Vale St., Pitești, Romania e-mail: dianamaria.ilie@ yahoo.com

\begin{abstract}
"The right is the totality of the conditions under which the will of each can coexist with the will of all, according to a universal law of freedom".Immanuel Kant.

The requirement that the expression of will to be uncorrupted is a legal necessity, but also a guarantee of compliance with the principle of freedom of civil legal acts, the real principle of will and the principle of law which enshrines the legal equality of the parties to civil legal relationship since the legal civil act must be the consequence of a volitional attitude, free and conscious expressed
\end{abstract}

KEYWORDS: civil legal act, consent, vices of consent, error, fraud, violence, injury.

\section{INTRODCTION}

The Civil code expressly states in art. In 1166 the notion of contract as wills agreement between two or more persons with intent to establish, modify or extinguish a legal report.

Essential for civil legal act is the manifestation of will of the party or parties and their intention on it to produce, within the objective law, legal effects. ${ }^{1}$ Examination of legal will is required in this context because, as we know, civil legal act is exactly a manifestation of will committed with the intent to produce legal effects.

In order for the civil legal act to produce legal effects and to be fully valid, as it follows from the above, it is necessary for the will to be uncorrupted. This condition is fulfilled when the will is free and undisturbed in its manifestations. ${ }^{2}$

The manifestation of will may be expressed precise or tacitly and is "thecore" of the civil legal act, the one that sets in motionthe creation of the legal act, so when it's missing this will we are dealing with a legal act. The will is psychological and appears as a complex

\footnotetext{
${ }^{1}$ Muţiu, M. I., (2001), Drept civil. Parteageneralăşisubiectele, Oradea, EdituraImprimeriei de Vest, p. 90

${ }^{2}$ Hamangiu, C., RosettiBălănescu, I., Baicoianu, Al. Tratat de dreptcivilroman, vol.I, Bucharest, EdituraAll, p.81.
} 
phenomenon. It interested, however, civil law directly, because there is a close correlation between will and consent, and the consentis a substantive condition for any civil legal act. In terms of legal, the structure of will comprises two elements: consent and cause (purpose). ${ }^{3}$

The consent appears in the legislation as a condition of substance, general, essential, of validity of civil legal act.Consent means expressing the decision to conclude a civil legal act. ${ }^{4}$ As a general rule, parties are free to choose the form of an expression of their will, apart from the exceptions expressly provided for by law, as is the case for legal acts which the law requires that the expression of will to put on a special form. ${ }^{5}$

The civil code stipulates in art. 1204 conditions of validity of consent, which must be cumulatively met, namely, to be serious, free and expressed learnedly. Some authors consider that should be met other requirements too, such as consent to be serious and precise. ${ }^{6}$

In order to be free, consent must be uncorrupted, respectively not to be impaired by vices altering it.

The vices of consent can be defined as those circumstances affecting the nature of consciousness and the free will to conclude a legal act.

According to the legislation in force, namely the Civil Code, consent is corrupted when given in error, surprised by fraud or torn by violence. Also, consent is vitiated in case of injury.

\section{THE ERROR}

The error is, as noted in the special literature, to believe what is truly false or false. ${ }^{7}$ In other words, the error is a false representation of reality at the conclusion of a civil legal act.

The classification of the error can be made in relation to three criteria, namely the consequences that occur, the nature of the false reality represented, as well as whether it is imputable to the misleading party.

Depending on the consequences, we are going to distinguish between essential error and nonessential error.

According to art. 1207 al. 2 Civil Code, the error is essential if the false representation falls on: the nature or the object of the legal act that is concluded (error in negotium), the physical identity of the object of the benefit (error in corpore),), the substantial qualities of the object of the benefit or other circumstances considered to be essential in the absence of which the legal act had not been concluded (error in substantiam) or the identity of the person or the quality of the person in the absence of which the contract would not have been concluded (error in personam).

The non-essential (irrelevant) error is the false representation of less important circumstances at the conclusion of the legal act in the sense that the mistaken party would have concluded the legal act and had a fair representation of those circumstances, so that the very validity it. The nonessential error may at most result in a reduction (or increase) in the value of the benefit, but it may even remain without any legal consequence. ${ }^{8}$

Depending on the nature of the false reality represented, the error may be:

In fact, what is the false representation of a state or factual situation at the conclusion of the civil legal act? It concerns either the object of the legal act or its value, or the co-contracting or beneficiary of the unilateral legal act.

\footnotetext{
${ }^{3}$ Ionaşcu, T., Barasch, E. (1967),Tratat de dreptcivil,vol.I,partea generală,Bucharest, EdituraAcademiei, p. 252.

${ }^{4}$ Boroi, G., Anghelescu, C.A. (2012), Curs dedreptcivil: parteagenerală, ediţia a 2-a revizuităşiadăugită, Bucharest, EdituraHamangiu, p. 131

${ }^{5}$ Boroi, G., Stănciulescu L. (2012), Instituţii de dreptcivilinnreglementareanouluiCodcivil, Bucharest, EdituraHamangiu, p. 94

${ }^{6}$ Ionaşcu, T. (1967), Consimţământul, caelement al voinţeijuridice, inTratat de dreptcivil, vol. I, Parteagenerală, Bucharest, Ed. Academiei, p. 263, 264

${ }^{7}$ Deleanu, I. Cunoaşterealegiişieroarea de drept, in Dreptul no.7/2004, p.45

${ }^{8}$ Boroi, G., Anghelescu, C.A. (2012), Curs dedreptcivil: parteagenerală, ediţia a 2-a revizuităşiadăugită, Bucharest, EdituraHamangiu, p. 144
} 
- Legally, consisting in the false representation at the conclusion of the legal act of the existence or content of a legal norm, cannot be invoked in the case of accessible and predictable legal provisions.

As it is attributable to the misleading part of the misleading party, we can distinguish the excusable error that cannot be accused of the party who had a false representation of reality at the conclusion of the legal act, which is not the result of the lack of information or negligence of that party and the inexcusable error, being that fault attributable to the party because the fact that it was carrying the error could be known with reasonable diligence.

Because the false representation of reality at the conclusion of a legal act is a vague consent, two requirements (conditions) must be met cumulatively: ${ }^{9}$

- the factual or legal element on which the error occurred was decisive, decisive for the conclusion of the legal act, in the sense that if the reality had been known the act would not have been concluded;

In the case of bilateral or plurilateral legal acts, for consideration, the other contracting party must have known or should have known that the item on which the false representation falls is essential to the conclusion of the respective civil legal act.

In case of essential error, in any of its forms, according to art.1207 al. 1 Civil Code, where the he relative nullity of the legal act intervenes as a sanction.

\section{THE DEFRAUD}

The Civil Code enshrines art. 1214 of this vitiation of consent, and AL. (1) of that article provides: "consent is vitiated by a party where the defraud has been in error as a result of fraudulent misconduct of the other party or when the latter has fraudulently omitted to inform the Contractor of circumstances was required to reveal it. "

The Romanian legal doctrine defines the defraud as the vitiation of conspiracy to mislead a person by means of cunning or dowry means to make it conclude a certain legal act. Therefore, in essence, the dumb is a provocative error and not spontaneous as in the case of the actual error. ${ }^{10}$

As a vice of consensus, the slop is made up of two elements:

An objective element (material) that consists in the use of sneaky means (fraudulent manipulation, chirping, etc.) to mislead. It can consist of both an action (committing action) and an inaction (omission);

- A subjective (intentional) element consisting of the intention of misleading a person to cause her to conclude a particular legal act. ${ }^{11}$ It is important to note that making a mistake of simple negligence, without a bad faith, is not a downside.

Initially, the silence on the decisive elements at the conclusion of the contract was not recognized as a vague consent but exceptionally. Later, it was argued that we can talk about reluctance if the law claims information. It is now unanimously considered that the reluctant idiom is a vague consensus that can attract the cancellation. ${ }^{12}$

The only requirement of the mine, which comes out of art.1214 and art. 1215 Civil Code, it is that the inferior comes from the other party, from the representative, the agent of the other party or a third party, unless the other party knew or ought to have known the existence of the dollar at the conclusion of the contract.

Since the inferiority is not presumed (Article 1214 paragraph 4 of the Civil Code), the person requesting the annulment of the civil legal act on the grounds that he has had the vicious

\footnotetext{
${ }^{9}$ Vasilescu, P., (2012), Dreptcivil. Obligaţii, Bucharest,EdituraHamangiu, p. 333-335

${ }^{10}$ Boroi, G., Anghelescu, C.A., Curs dedreptcivil: parteagenerală, ediţia a 2-a revizuităşiadăugită, EdituraHamangiu, Bucharest, 2012, p. 149

${ }^{11}$ Boroi, G., Anghelescu, C.A. (2012), Curs dedreptcivil: parteagenerală, ediţia a 2-a revizuităşiadăugită, Bucharest, EdituraHamangiu, p. 151

${ }^{12}$ Popa, I.F., Obligaţia de informare incontractelesinalagmatice, inDreptul no.7/2002, p.65.
} 
consent through the defraud must prove the dowry. Unlike the error test, the doll test is much easier to do because of its material element.

If the consent of one of the parties is vitiated by the defraud, the sanction that comes is the relative nullity of the respective legal act.

\section{THE VIOLENCE}

Violence is that vitiation of consent that consists in threatening a person with an evil that can produce, without right, a fear that leads him to conclude a legal act that he would not otherwise have concluded. ${ }^{13}$

Unlike the dollar and error, where the victim does not realize they are acting under their empire, in the violence she is aware that she does not have to conclude, modify or quit the legal act but cannot withstand violence so she prefers to do so in order to avoid the evil it is threatened with. ${ }^{14}$

In the legal doctrine, two criteria for classifying violence-consensus vice have been identified: the nature of the evil that threatens and the nature of the threat. ${ }^{15}$

According to the nature of the evil that is threatened, violence can be physical (dream), when the threat of harm refers to the physical integrity or property of a person or moral (metus) exists when the threat of harm refers to honor, honor or feelings to a person.

In relation to the nature of the threat, there is a distinction between the legitimate (right) and the evil threat, which does not constitute a vitiation of consent, thus not affecting the validity of the legal act, but violence is the fear inspired by the threat of exercising a right made in order to obtain unjust advantages and the unlawful (not right) threat with an evil that seeks to induce a fear without right, so that it constitutes a vitiation of consent, drawing the relative nullity of the legal act concluded under its empire.

As a structure, violence-vice of consent has two elements:

- $\quad$ an external, objective object, consisting of threatening with evil;

- a subjective internal element of a psychological nature, consisting in instigating fear of the person in danger, which causes the person against whom the violence is to conclude a legal act that he would not otherwise have concluded.

In order for violence to constitute a defect of consent, three requirements must be met cumulatively: the instigated fear is decisive for the conclusion of the civil legal act, the threat to be unjust (unlawful, unjustified when it is a violation of the law) bilateral and plurilateral legal, the threat comes from the other party or, if it comes from a third party, the co-contractor knew or ought to have known the violence committed by the third party.

The sanction that intervenes in the case of violence is, as it results from art. 1216 par. 1 Civil Code, the relative nullity of the legal act.

Exceptionally, violence can also lead to the absolute nullity of the legal act, namely when, because of it, consent is completely absent, for example, a person is forced to sign the document of a legal act by other persons lead his hand to sign. ${ }^{16}$

\section{THE INJURY}

\footnotetext{
${ }^{13}$ Boroi, G., Anghelescu, C.A. (2012), Curs dedreptcivil: parteagenerală, ediţia a 2-a revizuităşiadăugită, Bucharest, EdituraHamangiu, p. 154

${ }^{14}$ Diaconescu, H. Violenţa-viciu al voinţei juridice şi efectele ei în dreptul civil şi penal, cu privire specială la sancţiunea juridică a acesteia., in Dreptul no.6/2003, pp.65-66.

${ }^{15}$ Boroi, G., Anghelescu, C.A., Curs dedreptcivil: parteagenerală, ediţia a 2-a revizuităşiadăugită, EdituraHamangiu, Bucharest, 2012, p. 155

${ }^{16}$ Hamangiu, C., RosettiBalanescu, I., Baicoianu, Al., Tratat de dreptcivilromân,vol.II, Bucharest,EdituraAll p.501
} 
The injury is regulated in Art. 1221 Civil Code which states that "there is a lesion when one of the parties, taking advantage of the state of need, the lack of experience or the lack of knowledge of the other party, stipulates in favor of himself or another person a benefit of considerable value higher than the amount of its own benefit at the time of the conclusion of the contract."

Injury means material damage suffered by one of the parties as a result of the conclusion of a contract. As a rule, the lesion consists in the apparent disproportion of value between benefits, which exists even at the time of conclusion of the contract (laedere - injuries, laesio - wound, injury, damage).

The structure of the injury differs according to the conception underlying its regulation, and there are two concepts in this respect. ${ }^{17}$

Within the objective conception, the lesion involves only one element, namely material damage equal to the disproportion in value between the benefits.

According to the subjective conception, the lesion involves two elements: an objective element, consisting in the disproportion of value between contraptions and a subjective element, consisting in taking advantage of the special situation in which the co-contractor is found.

Our doctrine devotes both concepts.

According to the legislation, we have to distinguish between the minor injury and the major injury.

As regards the injury in the case of a minor, it may be invoked if it is a legal act that fulfills the following requirements: to be a civil legal act of administration; be a bilateral legal act, for consideration and commutative; be concluded by the juvenile between 14 and 18 years of age alone (the minor with restricted exercise capacity), without the consent of the legal guardian; to be detrimental to the minor.

In order for a major to claim the injury, two requirements must be met cumulatively: to prove the existence of a manifestly disproportionate value between benefits visible from the moment the contract is concluded; manifestly disproportionate to intervene as a result of the provision by the other party, at the date of the conclusion of the contract, of a benefit considerably higher than its own benefit, taking advantage of its state of need, lack of experience or lack of experience.

Art. 1222 al. 1 Civil Code states that "the party whose consent has been vitiated by the damage may request, at its option, the cancellation of the contract or the reduction of its obligations with the amount of damages to which it would be entitled", but the text has a poor wording because, depending on the situation the injured party may require the benefit of the other party to be increased.

So the injury can lead to two alternative sanctions:

- Relative nullity;

- Reducing or, as the case may be, increasing one of the benefits.

\footnotetext{
${ }^{17}$ Boroi, G., Anghelescu, C.A. (2012), Curs dedreptcivil: parteagenerală, ediţia a 2-a revizuităşiadăugită, Bucharest, EdituraHamangiu, p. 159
} 


\section{CONCLUSIONS}

We can say that what explains and justifies vices of consent is freedom of will, as an extension of the person's freedom. "Free legal arbitrariness" means the possibility for each person to choose a certain behavior, materialized by the conclusion of legal transactions. Violations of consent have not only a purely theoretical interest but also have an undeniable practical importance.

\section{BIBLIOGRAPHY}

1. Boroi, G., Anghelescu, C.A. (2012), Curs dedreptcivil: parteagenerală, ediţia a 2-a revizuităşiadăugită, Bucharest, EdituraHamangiu

2. Boroi, G., Stănciulescu L. (2012), Instituţii de dreptcivilinneglementareanouluiCodcivil, Bucharest, EdituraHamangiu

3. Deleanu, I. Cunoaşterealegiissieroarea de drept, in Dreptul no.7/2004

4. Diaconescu, H. Violenţa-viciu al voinţeijuridiceşiefecteleeî̂ndreptul civil şi penal, cu privirespecială la sancţiuneajuridică a acesteia., inDreptul no.6/2003

5. Hamangiu, C., RosettiBalanescu, I., Baicoianu, Al., (1998), Tratat de dreptcivilromân, Bucharest,EdituraAll

6. Ionaşcu, T. (1967), Consimţământul, caelement al voinţeijuridice, inTratat de dreptcivil, vol. I, Parteagenerală, Bucharest, Ed. Academiei

7. Ionaşcu, T., Barasch, E. (1967),Tratat de dreptcivil,vol.I,partea generală, Bucharest, EdituraAcademiei

8. Muţiu, M. I., (2001), Drept civil. Partea general şisubiectele, Oradea, EdituraImprimeriei de Vest

9. Popa, I.F.Obligaţia de informareîn contractile sinalagmatice, inDreptul no.7/2002

10. Vasilescu, P., (2012), Drept civil. Obligaţii, Bucharest,EdituraHamangiu 